\title{
Revision after Shoulder Surgery
}

\author{
회전근 개 재파열 후 봉합술 \\ 김경일•정진영 \\ 가톨릭대학교 성빈센트병원 정형외과
}

\section{Revisional Rotator Cuff Repair}

\author{
Kyungil Kim, M.D. and Jinyoung Jeong, M.D. ${ }^{\circledR}$ \\ Department of Orthopedic Surgery, The Catholic University of Korea, St. Vincent's Hospital, Suwon, Korea
}

Most patients experience pain relief and functional improvement after arthroscopic rotator cuff repair. In some patients, however, symptoms still remain after surgery. Failed rotator cuff repair is a complex outcome of biological, technical, and traumatic factors. Moreover, re-tears might or might not be the main cause for patients with persistent pain after rotator cuff repair. Therefore, a thorough understanding of the patient's history, physical examination, and appropriate imaging studies will be needed to evaluate and manage these patients. The patient's age, functional requirement, quality of the rotator cuff, preoperative range of motion, quality of the deltoid, and glenohumeral arthritis are factors to consider before performing revisional rotator cuff repair. Preoperative patient education is as important as the surgical technique for successful revisional rotator cuff repair.

Key words: rotator cuff repair, arthroscopic rotator cuff repair, failed rotator cuff repair, revisional rotator cuff repair, arthroscopic revisional rotator cuff repair

\section{서 론}

회전근 개 질환은 어깨 질환 중 가장 흔하게 수술적 치료를 하는 질병이다. 회전근 개 수술 시행 건수는 꾸준히 증가하고 있다.,2) 회전근 개 수술의 목적은 첫째, 통증을 없애는 것이고, 둘째, 회전 근 개 기능 및 근력을 회복시키는 것이다. 회전근 개 손상의 크기 에 따라 차이가 있으나 회전근 개 봉합술 후 건 회복 실패율은 약 $20 \%$ 정도로 보고되고 있다. 특히 소파열의 경우 $35 \%$ 정도로 보 고되나 대파열(여러 건 침범)의 경우 $94 \% \%^{8,9}$ 까지 보고된다.

회전근 개 봉합술 후 추시 영상 검사에서 잔존 파열 혹은 재파 열이 보이더라도 많은 수의 환자들은 통증이 경감되어 만족도가

Received August 7, 2018 Revised October 23, 2018

Accepted January 28, 2019

Correspondence to: Jinyoung Jeong, M.D.

Department of Orthopedic Surgery, The Catholic University of Korea, St. Vincent's Hospital, 93 Jungbu-daero, Paldal-gu, Suwon 16247, Korea

TEL: +82-31-249-7186 FAX: +82-31-254-7186 E-mail: osjeong@hotmail.com

ORCID: https://orcid.org/0000-0003-0047-5391
높지만 일부 환자들에서는 추가적인 치료를 필요로 하는 조절되 지 않는 심각한 통증과 기능장애를 보인다.

회전근 개 봉합술 후 재파열이 발생하는 원인은 여러 가지가 있으나 봉합술 시 약한 건 고정, 생물학적 치유 실패, 수술 후 부 적절한 재활 등 3 가지를 주요 요소로 들 수 있다.

\section{병태생리학}

회전근 개 봉합술 후 재파열은 회전근 개 부착부 약화 및 회전근 개 혈행의 감소 등 2 가지 병태생리학적 요인에 의해 발생한다. 정 상에서는 힘줄-뼈 부착부의 결합조직이 있지만 봉합술 후에는 이에 비해 생역학적으로 약한 섬유혈관성 반흔 조직(fibrovascular scar tissue)이 형성되어 상대적으로 취약하다. ${ }^{10)}$ 하지만 아직까지 대부분의 연구는 동물 실험으로 이루어졌고 인간을 대상으로 한 연구는 거의 없다. 회전근 개의 혈액 공급이 건 치유의 중요한 요 인으로 정상 회전근 개는 나이가 들어감에 따라(특히 40세 이상 에서) 혈액 공급이 떨어질 뿐 아니라 ${ }^{11)}$ 관절경적 봉합술 후 3 개월 
째 치유되는 건은 상대적으로 무혈관성이며 그나마 혈액 공급은 뼈에서 이루어지므로 ${ }^{22}$ 건 치유에 좋은 환경이 아니다.

회전근 개 봉합술 후 약화된 힘줄-뼈 부착부 회복에 도움을 주 기 위해 생물학적 보강(biologic augmentation)으로 동물실험이 나 일부 생체실험에서 사용되었던 성장인자, 자가혈(platelet-rich plasma), 인공합성 이식물 등을 적용하기도 한다. ${ }^{13)}$

하지만 봉합술의 술기 자체가 힘줄-뼈 부착부 회복의 중요한 선행 인자가 될 것이다. ${ }^{14}$ 최근 사체연구에서 일열 봉합술보다 이 열 봉합술이나 교량형 이열 봉합술(경골 유사 봉합술, transosseous equivalent repair)이 생역학적으로 우수하고, ${ }^{15)}$ 영상의학적 추 시에서도 향상된 건 치유를 보였다. ${ }^{16-18)}$ 일열 봉합술도 봉합사 세 개가 포함된 나사못(anchor)을 사용해서 고정 수를 늘리거나 봉 합 배치를 수정하여 봉합사로 인해 발생하는 건 열상(cutout)을 줄 이고 좋은 결과를 기대할 수 있다. ${ }^{19)}$ 이열 봉합술은 봉합한 내측 의 근-건 이행부의 파열 ${ }^{20}$ 과 이미 약화된 혈관에 혈액 공급을 더 제한한다는 단점이 보고되고 있으나, ${ }^{21)}$ 최근까지 무작위 연구로 이루어진 임상 결과는 이열 봉합술과 일열 봉합술 간의 유의한 차이는 없었다. ${ }^{16,18}$

\section{기 전}

\section{1. 생물학적 요인}

회전근 개 봉합술 후 재파열의 생물학적 요인으로 나이, 지방변 성, 근위축, 동반 질환(당뇨병 등), 흡연을 들 수 있다. 나이가 들어 감에 따라서 건으로 가는 미세 순환이 떨어져서 회전근 개 봉합 술 후에 치유율이 떨어질 수 있다.,422-26) 파열 크기나 파열된 건의 수, 건의 상태도 중요한 요인이며, 3,4,6,24-30) 파열 크기가 $1 \mathrm{~cm}$ 증가 할 때마다 재파열의 위험성은 2 배씩 증가한다고 보고하였다. ${ }^{25}$ 파 열된 회전근 개의 지방 변성과 위축은 회전근 개 봉합술의 나쁜 예후 인자이다. 지방 변성은 술 전 영상검사에서 Goutallier 분류 로 평가한다(Table 1). ${ }^{31)}$

지방 변성과 근 위축은 회전근 개 봉합술을 어렵게 하며 성공 적인 봉합술 후에도 잔존 파열이 남아 있으면 지방 변성과 근 위 축은 계속 증가할 수 있다. ${ }^{32-34)}$ 파열이 오래될수록 지방 변성은 증 가하는데, 증상의 시작 3 년 후에는 중등도의 지방 변성을 보이고

Table 1. Goutallier Fatty Degeneration Classification

\begin{tabular}{ll}
\hline Grade 0 & Completely normal muscle, without any fatty streak \\
Grade 1 & Muscle contains some fatty streaks \\
Grade 2 & $\begin{array}{l}\text { Fatty infiltration is important, but there is more muscle } \\
\text { than fat }\end{array}$ \\
Grade 3 & Equal amounts of fat and muscle \\
Grade 4 & More fat than muscle is present \\
\hline
\end{tabular}

5년이 경과하면 심한 지방 변성을 보인다. ${ }^{35)}$ 지방 변성과 근 위축 이 증가할수록 봉합 부위의 긴장이 증가하는 것은 임상 연구 ${ }^{36}$ 및 동물실험 37,38 에서 증명된 바 있다. 극하건 파열 동물 실험에서 조 기에 봉합한 군에서 더 빠르게 근 기능, 건 탄성이 회복되었고, 지 연 봉합한 군에서는 조기 봉합한 군에 비해 근 기능, 건 탄성이 떨 어졌으명) 임상연구에서도 조기 봉합한 군에서 임상 결과가 우 수한 것으로 보고되었다. ${ }^{40}$ 하지만 Park 등 ${ }^{41)}$ 은 술 전 극상건의 지 방 변성과 술 후 건 치유에는 큰 상관관계가 없고 오히려 극하건 및 견갑하건의 지방 변성이 건 치유에 큰 상관관계가 있다고 보 고하였다. 이 외에 당뇨 ${ }^{42-44)}$ 등의 동반 질환이나 흡연 ${ }^{45,46}$ 이 회전 근 개 치유를 방해하는 것으로 알려져 있다.

\section{2. 기술적 요인}

술자의 숙련도 부족도 회전근 개 봉합술 후 재파열의 위험 인자 가 될 수 있다. ${ }^{4)}$ 전체 회전근 개의 병변을 볼 수 있는 시야 확보 기술 및 파열된 건을 가동화시키는 방법, 추가로 동반된 다른 병 변을 찾아내는 기술 등이 성공적인 수술과 술 후 통증을 줄여주 는 데 중요하다. 개방적 복원술, 최소 절개 복원술 혹은 관절경적 복원술 등 수술 방법에 상관없이 가장 중요한 것은 파열된 부위 의 시야 확보이다. 관절경적 복원술은 삼각근 부착부를 보존하면 서 여러 가지 삽입구를 통해 충분하게 시야 확보를 할 수 있다는 장점이 있는 반면 대파열 또는 광범위 파열에서 최소 절개 복원 술을 사용하는 경우는 작은 삼각근의 창으로 시야 확보가 잘 되 지 않고 회전근 봉합 후 절개한 삼각근을 견고히 고정해야 한다.

파열된 회전근 개는 시간이 지남에 따라 퇴축되고 점액낭 측과 관절면 측의 주변 조직과 유착되므로 건을 충분히 가동화시켜 긴 장되지 않게 봉합하는 것이 중요하다. 충분한 시야 확보 및 가동 화를 시킨 후에도 재파열을 피하기 위해서는 적절한 고정이 필요 하며 나사못의 골 고정력, 매듭의 안정성, 간섭 나사의 안정성, 봉 합 형태, 봉합 배치 등이 기술적 실패를 방지할 수 있는 중요한 요 소이다. 봉합 나사못을 이용한 회전근 개 봉합술 후 재파열은 많 은 경우에서 건-봉합 사이에서 발생하멱) 이런 건-봉합 사이에 서의 재파열을 막기 위해서 파열 양상 및 조직의 가동성의 허용 범위에서 mattress 봉합 등의 방법을 적용할 수 있다. ${ }^{17}$

회전근 개 파열은 건 내부의 퇴행성 변화와 견봉하 골극에 의 한 외부의 기계적 마모의 복합 작용으로 인해 발생한다. 비정상 적인 견봉의 모양이나 오구 견봉 인대 골화가 있는 환자에서 충 분하지 않은 견봉성형술이 재파열에 영향을 줄 수 있다. 비록 무 작위 연구에서 회전근 개 봉합술 시 견봉성형술의 일관된 임상적 이점을 보이지는 않았지만 회전근 개 봉합술 후 재파열 수술 시 견봉성형술이 이루어지지 않았던 견봉하 골극이나 부분 절제된 견봉하 골극으로 충돌을 시사하는 오구 견봉 인대의 마모가 적지 않게 확인되는 것으로 보고되고 있으며, ${ }^{48,49}$ Djurasovic 등 ${ }^{50}$ 에 따 르면 80예의 재파열 수술 중 약 2/3에서 불충분한 견봉하 성형술 
이 확인되었다.

\section{3. 외상적 요인}

외상은 회전근 개 봉합술 후 재파열의 중요한 요인이다. 외상으 로 인한 재파열은 건의 완전한 치유가 이루어지기 전이나 후 모 두에서 발생한다. 조기에 발생하는 재파열은 보통 특별한 문제 없이 지내다가 넘어진다거나 무리한 물리치료 후 갑자기 발생한 다. ${ }^{51)}$ 술자, 환자, 물리치료사들은 봉합술 후 적어도 3-4개월이 지 나야 봉합한 건의 성숙이 발생한다 ${ }^{52)}$ 는 것을 숙지하고 적절한 재 활 프로토콜을 따라야 한다. 지연 발생하는 재파열은 술 후에 술 전의 근력과 운동 범위를 회복한 후 새로운 외상에 의해 주로 발 생한다. 철저한 환자 평가(문진, 이학적 검사, 영상의학적 검사)를 통해서 회전근 개 봉합술 후 재파열의 발생에 기여한 요인을 파 악할 수 있으며, 재수술이 환자에게 필요할지 판단할 수 있을 것 이다.

\section{환자 평가}

회전근 개 봉합술은 대부분 임상 결과가 우수하지만, 잔존 파열 혹은 재파열률이 높으며 건 치유에 문제가 있는 일부 환자에서는 지속되는 통증과 위약감을 보일 수 있으므로 철저한 문진, 이학 적 검사, 영상의학적 검사가 필요하다.

\section{1. 문진 및 이학적 검사}

문진에서는 통증의 기간, 수상 날짜, 수상 기전, 활동력과 직업, 정 확한 과거력(전신 질환, 당뇨병, 흡연 등), 통증은 위치와 양상, 악 화 또는 완화 인자, 신경학적 증상의 유무, 경부 통증 등이 중요하 다. 초기 봉합술 후 통증이 경감되었는지 여부도 확인해야 하며 이전에 시행한 모든 수술을 확인해야 하고 타 의료기관에서 첫 수술을 시행했다면 그 병원의 의무기록(수술 기록, 술 전 영상, 관 절경 사진)을 파악하는 것이 필요하다. 또한 술 후 재활 프로토콜 과 고정 기간도 확인이 필요하다.

이학적 검사는 건측과 환측을 비교하고 이전 수술 부위가 잘 나았는지 구축, 염증, 발적, 압통 등은 없는지 확인한다. 관절경 수 술 후 감염은 드물지만 항상 의심하고 검사해야 된다. 감염이 있 을 때는 보통 일반적으로 회전근 개 기능 장애 시 보이는 활동과 관련된 간헐적인 양상의 통증이 아니라 지속적인 양상의 통증을 호소한다. Cutibacterium acnes (Propionibacterium acnes)가 견관절 의 관절경 수술 후 감염의 가장 흔한 원인균으로, $50 \%-86 \%$ 를 차 지하며 ${ }^{53,54}$ 감염 진단 시에는 즉시 세척술 및 변연절제술과 정맥 항생제로 치료한다.

술 전에 삼각근 기능이 좋지 않으면 재수술 후에도 결과가 좋 지 않으므로 ${ }^{50)}$ 삼각근 또는 회전근 개의 변형이나 위축도 확인을 요한다. 견갑하건, 견봉 쇄골 관절, 상완이두건 장두('Popeye’ 변
형 또는 압통 여부)도 검사하여 다른 통증의 원인이 있는지 확인 하여 재수술 시 같이 수술해야 한다. 능동적 및 수동적 관절 운동 범위(전방 거상, 외회전, 내회전)를 모두 검사해야 한다. 소파열의 경우 관절 운동 범위는 정상일 수 있고 과도한 굴곡 또는 회전 시 에만 통증이 나타날 수 있다. 그러나 대파열 또는 광범위형 파열 에서는 보통 능동적 관절 운동 범위의 제한이 있으며 수동적 관 절 운동 범위 제한도 수술 후 유착성 관절낭염이나 관절염으로의 진행 여부를 배제 하기 위해 검사가 필요하다.

삼각근, 극상근, 견갑하근, 외회전의 근력 검사도 건측과 비교 하여 시행해야 한다. 술 후 시행하는 자기공명영상(magnetic resonance imaging, MRI)은 이상 확인의 정확도가 떨어지므로 상대 적으로 근력 검사의 중요도가 증가한다. 신체 검사로 파열 크기 ${ }^{55)}$ 나 지방 변성 ${ }^{56}$ 도 가늠할 수 있다. 외회전 지연 검사(external rotation lag sign) 양성(팔꿈치 90도 굴곡, 어깨를 20도 거상한 채로 최 대 외회전을 유지하지 못함)은 $65 \%$ 민감도로 극하건 파열을 진단 할 수 있다. 근력 검사에 이어 충돌 검사(impingement test)도 시행 한다. 그리고 스펄링 검사(spurling test)도 경추 신경근병증을 배 제하기 위해 시행된다.

\section{2. 영상 검사}

초기 영상 검사로 단순 방사선 검사를 시행하는데 전후방 영상, 진성 전후방 영상(관절와 전후면상, Grashey view), 액와면 영상 (axillary lateral view), 극상건 출구 영상(supraspinatus outlet view) 을 촬영하여 견봉 쇄골 관절 상태, 견봉 하 골극, 견봉 쇄골 관절 하 골극, 대결절 상태(이전 나사못 삽입 상태), 골관절염에서 보이 는 관절와 상완 관절 간격의 감소나 골극이 있는지, 견봉 상완 간 격, 상완골 두의 상방 전위가 있는지를 평가한다. 재봉합술의 금 기가 되는 회전근 개 관절병증(고정된 상완골 두 상방 전위와 관 절염)을 확인하는 것이 중요하다. 그러나 관절염 없이 발생한 상 완골 두 상방 전위의 단독 병변은 재봉합술의 절대적 금기가 아 니므로 주의를 요한다. ${ }^{57)}$

회전근 개 병변의 진단에는 MRI가 가장 좋지만 수술 후에는 정 확도가 떨어지며 민감도는 $91 \%$ 로 여전히 높지만 특이도는 $25 \%$ 로 떨어지므로 과도한 진단의 가능성을 주의해야 한다. ${ }^{58)}$ 봉합 나 사못과 같은 삽입물로 인한 간섭이 있을 수 있으므로 봉합 나사 못의 수와 위치를 파악하고 주변 대결절의 골질을 확인하는 것이 술 전 계획을 세우는 데 중요하다. 가능하다면 첫 수술 전 촬영한 $\mathrm{MRI}$ 와 비교하는 것이 수술적 실패를 파악하는 데 도움이 된다. Trantalis 등 ${ }^{20)}$ 은 이열 봉합술 후 발생한 5 개의 재파열 증례 모두에 서 근-건 이행부에서 봉합이 이루어져 재파열이 내측열의 내측 에서 발생하였으며 Hayashida 등 ${ }^{59}$ 도 이열 봉합술 후 부착부 근처 는 잘 유지되나 내측열 근처에서 재파열이 발생하였다고 보고하 였다.

$\mathrm{MRI}$ 는 봉합술 후 재파열된 회전근 개의 복원 가능성을 평가하 
는 데 가장 중요한 검사 중 한 가지다. 회전근 개의 양상에 따른 봉합술 후 예후를 비교한 연구에서 시상면상 견갑골 부위에서 보 이는 근 위축 정도와 관상면상 보이는 퇴축 정도(대결절의 나사 못 위치에서 측정한 거리)가 중요한 것으로 보고하였으며 ${ }^{27}$ 관상 면상 건의 정점이 관절와 상완 관절보다 외측에 있고 Goutallier classification stage 3 이하인 경우 재봉합술의 시도가 가능하지만 지방 변성 자체가 재봉합술의 절대 금기가 되는 것은 아니다. ${ }^{60)}$

초음파 또한 술 후 회전근 개의 상태를 평가하는 데 있어 적용 할 수 있으며 재수술 시 시행되는 관절경 소견과 비교해 볼 때 초 음파는 민감도가 $91 \%$, 특이도가 $86 \%$, 술 후 회전근 개 상태 평 가 정확도가 89\%나 된다. ${ }^{61)}$ 관절 조영 컴퓨터 단층촬영 (computed tomography) 또한 회전근 개 평가를 위해 사용될 수 있지만 높은 방사선 노출로 인해 MRI를 시행할 수 없는 경우(심박조율기 등) 에 한해서 사용할 수 있을 것이다.

\section{보존적 치료의 결과}

Jost 등리은 20명의 회전근 개 봉합술 후 재파열된 환자를 보존적 치료하여 평균 38개월 추시 후 adjusted Constant score와 subjective shoulder value가 각각 83\%, 75\%를 보인다고 하였으며 Namdari 등 63 ) 은 보존적 치료 후 54\%의 환자에서 좋은 결과(American Shoulder and Elbow Surgeons [ASES] score 80점 이상)를 보이고 평균 52개 월 추시중 ASES score가 15점 향상되었다고 보고하였다.

\section{재봉합술의 결과}

개방성 재봉합술과 관절경적 재봉합술의 결과에 대해 비교 발표 한 연구에서 모두 좋은 결과를 보였지만 봉합술의 성공을 평가
하기 위해서는 연구를 다시 살펴볼 필요가 있다. 개방성 재봉합 술 관련 연구 중 Djurasovic 등이이 가장 많은 일련의 연구들을 보 고하였다. 재봉합술을 시행 받은 80 명의 환자를 분석하여 성공적 인 결과에 가장 큰 영향을 미친 요인은 1) 손상되지 않은 삼각근, 2) 회전근 개 조직의 양호한 상태, 3) 수술 전 능동 거상이 90도 이 상, 4) 선행하는 수술이 한 차례인 경우이며, 이 기준에 해당되는 경우 좋은 결과를 보였다. 여러 연구에서 $20,48,49,64)$ 모두 관절경적 재 봉합술이 통증과 기능 향상에 모두 성공적인 결과를 보였다고 한 다.

\section{재봉합술의 적응증}

회전근 개 봉합술 재파열의 수술적 치료 결정 시에는 1) 근 위축 과 건 퇴축의 정도를 확인할 수 있는 MRI에 근거한 파열의 복원 가능성, 2) 능동적 관절 운동 범위(술 전 90도 미만의 전방 거상 은 나쁜 예후), 3) 삼각근의 상태(삼각근 상태가 좋지 않으면 나쁜 예후), 4) 수술 횟수(2회 이상의 수술 횟수는 나쁜 예후), 5) 엄격 한 재활 프로토콜에의 확고한 시도, 6) 기능적 요구도, 7) 통증의 정도 등을 고려해야 한다. 상대적으로 젊은 나이, 높은 기능적 요 구, 위축 없이 봉합 가능한 파열, 술 전 관절 운동 범위가 좋은 경 우, 손상되지 않은 삼각근, 선행하는 수술이 한 번인 경우가 재봉 합술의 가장 좋은 적응증이 될 수 있다. 그러나 이러한 경우는 많 지 않기 때문에 비수술적 치료가 회전근 개 봉합술 후 재파열에 서 적절한 경우가 있을 수 있으며 전방 삼각근 강화 운동에 중점 을 둔 지속적인 재활이 권장된다. ${ }^{65)}$
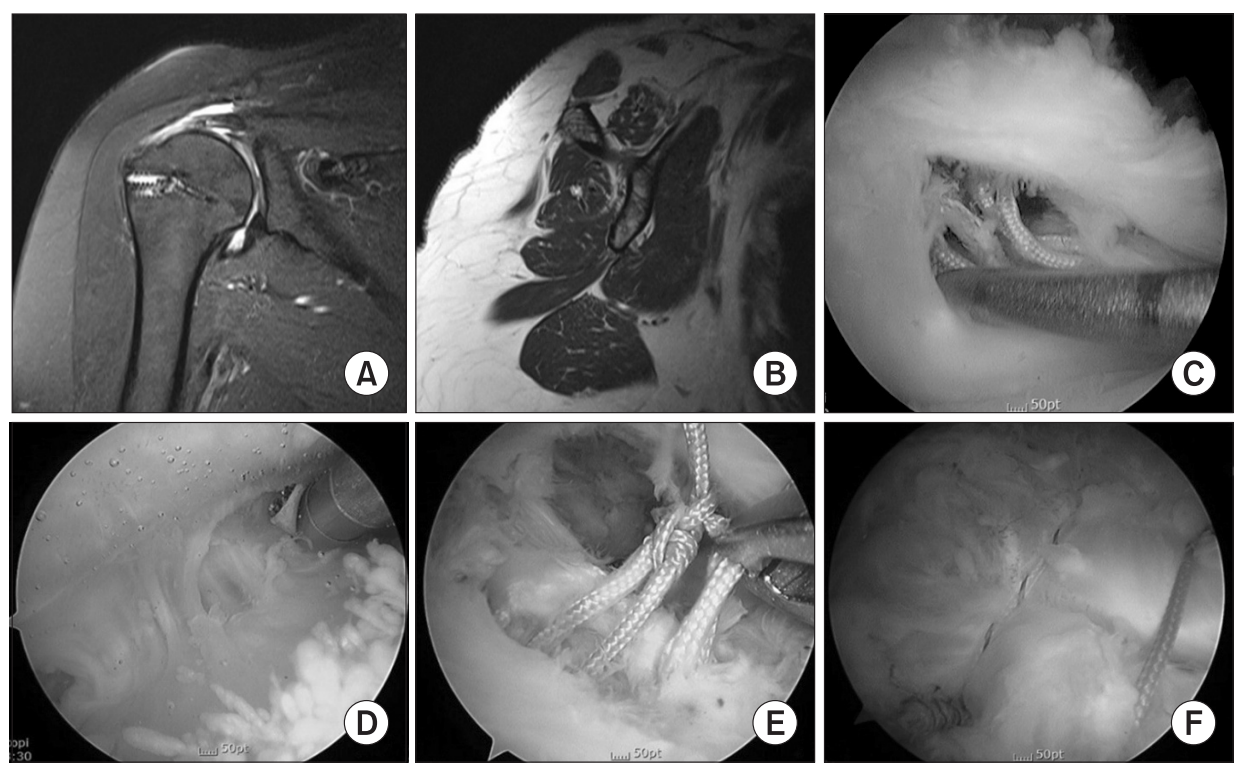

Figure 1. Revisional rotator cuff repair. (A, B) Tear at medial row of double row repair, minimal muscle atrophy and fatty degeneration on magnetic resonance imaging. (C) Dissociation of suture material with tear and a retraction of medial rotator cuff on a failed rotator cuff arthroscopic exam. (D) Separation of tissue from subacromial adhesion. (E) Retrieval of dissociated previous suture material. (F) Side-to-side repair of a retorn rotator cuff. 


\section{수술 술기}

관절경적 재봉합술 시 상완이두건 장두, 관절와, 관절와순, 견갑 하건에 대한 철저한 평가가 필요하다. 추가적인 견봉성형술이 필 요한 경우에는 너무 과도하게 견봉 절제가 이루어져 견봉 골절을 만들지 않도록 주의해야 한다. 재파열된 회전근 개 조직은 대체 로 상태가 좋지 않으며, 증가된 근 위축과 지방 변성을 보인다. ${ }^{20}$ 조심스럽게 회전근 개를 다루는 것이 의인성(iatrogenic) 조직 손 상을 막기 위해 중요하다. 전방 극상건과 전방 삼각근 사이 유착 은 전방의 회전근 개 움직임을 제한하며 회전근 개의 점액낭 측 과 관절면 측 모두 변인 절제를 시행하고 가능한 남아있는 봉합 사를 제거해야 된다. 회전근 개 부착부 덮힘(coverage)을 극대화 하기 위해 대결절을 조심스럽게 처치해야 된다. 조직 고정 위해 이열 봉합과 경골 유사 봉합술(교량형 이열 봉합술)을 고려할 수 있으며 삽입물이 관절경이나 영상검사에서 보이지 않아도 단단 하게 박혀 잔존하는 삽입물에 의한 봉합 나사못이 손상되지 않도 록 태핑(tapping)이 조심스럽게 이루어져야 한다. 금속 삽입물은 제거 시 큰 골 결손을 만들어 대결절을 약하게 만들고 고정력에 문제를 일으킬 수 있는 경우는 제거하지 않는다. 헐겁거나 융기 된 봉합 나사못은 제거하는 것이 좋다. 새로운 봉합 나사못을 이 전의 봉합 나사못 구멍(track)으로 넣을 때는 견고한 고정을 위해 더 큰 크기의 나사못을 사용할 수 있으며 골 결손이 봉합 나사못 의 사용을 제한한다면 경골 봉합술(transosseous techniques)을 이 용할 수 있다(Fig. 1).

퇴축된 광범위 회전근 개 재파열의 해부학적 봉합을 위하여 광 범위한 건 가동화가 필요할 수 있으나 가동화되었다고 해도 조직 의 상태가 좋지 않아 봉합 부위에 추가적인 구조적 보강을 요할 수 있다. 다양한 종류의 생물학적 보강, 즉 이종이식물(돼지 피부 콜라겐, 돼지 소장 점막하층) 혹은 합성물(콜라겐이 풍부한 세포 외 기질, collagen rich extracellular matrix)이 사용될 수 있다. ${ }^{60}$ 최 근 발표된 메타분석에서 생물학적 보강이 재파열율을 의미있게 낮춘다는 보고가 있다. ${ }^{67)}$

극관절와 또는 상견갑 절흔에서 신경이 당겨지거나 단단하거 나 골화되어 있는 극관절와 또는 견갑횡인대에 압박되는 경우 상 견갑신경병증이 나타나기도 하며 퇴축되어 있는 회전근 개 파열 에 의해 상견갑 절흔에 있는 견갑극에 상견갑신경이 긴장이 걸릴 수 있다. 회전근 봉합술 시 건의 가동화는 상견갑신경의 긴장을 줄여주어 상견갑신경병증의 치료로 사용되기도 하며, ${ }^{68)}$ 광범위 회전근 개 파열 시 상견갑 절흔을 감압하기도 한다. ${ }^{69}$

술 전 검사에서 견봉쇄골관절의 상태와 상완이두건의 상태를 확인하고 동반되어 있는 상완이두건막염이나 견봉쇄골관절병증 에 대해서도 치료를 시행해야 된다.

\section{환자 교육}

회전근 개 재봉합술을 시행하기 전 환자와 충분한 대화는 필수적 이며 술자는 환자에게 자신의 상태에 대해서 교육하고 술 후 환 자의 기대를 적절한 수준으로 조절하는 것이 필요하다. 증가된 환자의 기대는 술 후 결과에 안 좋은 영향을 미칠 수 있으므로 환 자는 자신의 상태에 대해서 반드시 이해하고, 재수술의 목표와 이로 인해 발생 가능한 합병증을 충분히 알고 있어야 한다.

$\mathrm{Craig}^{70}$ 와 Bell과 Noel ${ }^{71)}$ 은 회전근 개 봉합술 전 환자와의 대화 와 재수술 시 1) 회전근 개 수술을 하는 첫 번째 목적은 통증을 줄 이는 것이고, 기능의 회복은 부수적으로 따라 오는 것이며 어깨 는 절대 이전의 정상 상태로 돌아갈 수 없다는 점, 2) 재봉합술은 재파열의 위험성이 첫 수술에 비해 횔씬 높고 파열이 크면 추후 관절염이 생길 수 있다는 점, 3) 비록 재수술이 통증과 기능을 향 상시키지 못하더라도 관절경으로 행해지기 때문에 더 악화될 가 능성은 드물다는 점, 4) 재활은 적어도 4-6주간 보조기를 착용 후, 6 주의 수동적 관절 운동, 6 주의 능동적 관절 운동, 6 주의 근력강화 운동으로 구성되며 6개월 동안 통증, 강직이 지속될 수 있으나 1 년까지 조금씩 나아질 수 있다는 점에 대해 강조하였다.

\section{요 약}

회전근 개 봉합술은 제대로 시행되고 재활을 적절히 하였을 때 매우 성공적이다. 적절히 치유된 회전근 개는 지속적으로 향상되 는 임상 결과를 나타낼 것이나 적절한 가동화와 회전근 개의 견 고한 고정이 되어도 특히 퇴축과 위축을 동반한 대파열에서는 재 파열이 발생할 가능성이 높다. 회전근 개 봉합술의 실패는 생물 학적 인자들과 관련하여 나이, 파열 크기, 지방 변성 등 여러 가지 요인에 의해 발생할 수 있으며, 이외에도 환자 관련 인자(당뇨, 흡 연 등), 외상, 수술 술기의 오류 또한 회전근 개 봉합술 실패 여부 에 중요하다.

증상이 있는 재파열 환자를 치료할 때 적절한 재봉합술은 성공 적인 조치가 될 수 있지만 환자 선별이 중요하고, 환자의 기대치 를 조절하는 것이 무엇보다 중요하다.

\section{CONFLICTS OF INTEREST}

The authors have nothing to disclose.

\section{REFERENCES}

1. Pedowitz RA, Yamaguchi K, Ahmad CS, et al. Optimizing the management of rotator cuff problems. J Am Acad Orthop Surg. 2011;19:368-79. 
Kyungil Kim and Jinyoung Jeong

2. Colvin AC, Egorova N, Harrison AK, Moskowitz A, Flatow EL. National trends in rotator cuff repair. J Bone Joint Surg Am. 2012;94:227-33.

3. Gazielly DF, Gleyze P, Montagnon C. Functional and anatomical results after rotator cuff repair. Clin Orthop Relat Res. 1994;304:43-53.

4. Harryman DT 2nd, Mack LA, Wang KY, Jackins SE, Richardson ML, Matsen FA 3rd. Repairs of the rotator cuff. Correlation of functional results with integrity of the cuff. J Bone Joint Surg Am. 1991;73:982-9.

5. Knudsen HB, Gelineck J, Søjbjerg JO, Olsen BS, Johannsen HV, Sneppen O. Functional and magnetic resonance imaging evaluation after single-tendon rotator cuff reconstruction. J Shoulder Elbow Surg. 1999;8:242-6.

6. Liu SH, Baker CL. Arthroscopically assisted rotator cuff repair: correlation of functional results with integrity of the cuff. Arthroscopy. 1994;10:54-60.

7. Wülker N, Melzer C, Wirth CJ. Shoulder surgery for rotator cuff tears. Ultrasonographic 3-year follow-up of 97 cases. Acta Orthop Scand. 1991;62:142-7.

8. Calvert PT, Packer NP, Stoker DJ, Bayley JI, Kessel L. Arthrography of the shoulder after operative repair of the torn rotator cuff. J Bone Joint Surg Br. 1986;68:147-50.

9. Galatz LM, Ball CM, Teefey SA, Middleton WD, Yamaguchi $\mathrm{K}$. The outcome and repair integrity of completely arthroscopically repaired large and massive rotator cuff tears. J Bone Joint Surg Am. 2004;86-A:219-24.

10. Gulotta LV, Rodeo SA. Growth factors for rotator cuff repair. Clin Sports Med. 2009;28:13-23.

11. Rudzki JR, Adler RS, Warren RF, et al. Contrast-enhanced ultrasound characterization of the vascularity of the rotator cuff tendon: age- and activity-related changes in the intact asymptomatic rotator cuff. J Shoulder Elbow Surg. 2008;17:96S-100S.

12. Gamradt SC, Gallo RA, Adler RS, et al. Vascularity of the supraspinatus tendon three months after repair: characterization using contrast-enhanced ultrasound. J Shoulder Elbow Surg. 2010;19:73-80.

13. Strauss EJ, McCormack RA, Onyekwelu I, Rokito AS. Management of failed arthroscopic rotator cuff repair. J Am Acad Orthop Surg. 2012;20:301-9.

14. Montgomery SR, Petrigliano FA, Gamradt SC. Failed rotator cuff surgery, evaluation and decision making. Clin Sports Med. 2012;31:693-712.
15. Wall LB, Keener JD, Brophy RH. Double-row vs single-row rotator cuff repair: a review of the biomechanical evidence. J Shoulder Elbow Surg. 2009;18:933-41.

16. Nho SJ, Slabaugh MA, Seroyer ST, et al. Does the literature support double-row suture anchor fixation for arthroscopic rotator cuff repair? A systematic review comparing double-row and single-row suture anchor configuration. Arthroscopy. 2009;25:1319-28.

17. Burkhart SS, Cole BJ. Bridging self-reinforcing double-row rotator cuff repair: we really are doing better. Arthroscopy. 2010;26:677-80.

18. Duquin TR, Buyea C, Bisson LJ. Which method of rotator cuff repair leads to the highest rate of structural healing? A systematic review. Am J Sports Med. 2010;38:835-41.

19. Castagna A, Garofalo R, Conti M, Borroni M, Snyder SJ. Arthroscopic rotator cuff repair using a triple-loaded suture anchor and a modified Mason-Allen technique (Alex stitch). Arthroscopy. 2007;23:440.e1-4.

20. Trantalis JN, Boorman RS, Pletsch K, Lo IK. Medial rotator cuff failure after arthroscopic double-row rotator cuff repair. Arthroscopy. 2008;24:727-31.

21. Accousti KJ, Flatow EL. Technical pearls on how to maximize healing of the rotator cuff. Instr Course Lect. 2007;56:3-12.

22. Boileau P, Brassart N, Watkinson DJ, Carles M, Hatzidakis AM, Krishnan SG. Arthroscopic repair of full-thickness tears of the supraspinatus: does the tendon really heal? J Bone Joint Surg Am. 2005;87:1229-40.

23. DeFranco MJ, Bershadsky B, Ciccone J, Yum JK, Iannotti JP. Functional outcome of arthroscopic rotator cuff repairs: a correlation of anatomic and clinical results. J Shoulder Elbow Surg. 2007;16:759-65.

24. Cole BJ, McCarty LP 3rd, Kang RW, Alford W, Lewis PB, Hayden JK. Arthroscopic rotator cuff repair: prospective functional outcome and repair integrity at minimum 2-year follow-up. J Shoulder Elbow Surg. 2007;16:579-85.

25. Nho SJ, Brown BS, Lyman S, Adler RS, Altchek DW, MacGillivray JD. Prospective analysis of arthroscopic rotator cuff repair: prognostic factors affecting clinical and ultrasound outcome. J Shoulder Elbow Surg. 2009;18:13-20.

26. Keener JD, Wei AS, Kim HM, et al. Revision arthroscopic rotator cuff repair: repair integrity and clinical outcome. J Bone Joint Surg Am. 2010;92:590-8.

27. Davidson J, Burkhart SS. The geometric classification of rotator cuff tears: a system linking tear pattern to treatment and 
Revisional Rotator Cuff Repair

prognosis. Arthroscopy. 2010;26:417-24.

28. Bishop J, Klepps S, Lo IK, Bird J, Gladstone JN, Flatow EL. Cuff integrity after arthroscopic versus open rotator cuff repair: a prospective study. J Shoulder Elbow Surg. 2006;15:2909.

29. Huijsmans PE, Pritchard MP, Berghs BM, van Rooyen KS, Wallace AL, de Beer JF. Arthroscopic rotator cuff repair with double-row fixation. J Bone Joint Surg Am. 2007;89:1248-57.

30. Sugaya H, Maeda K, Matsuki K, Moriishi J. Repair integrity and functional outcome after arthroscopic double-row rotator cuff repair. A prospective outcome study. J Bone Joint Surg Am. 2007;89:953-60.

31. Goutallier D, Postel JM, Bernageau J, Lavau L, Voisin MC. Fatty muscle degeneration in cuff ruptures. Pre- and postoperative evaluation by CT scan. Clin Orthop Relat Res. 1994;304:78-83.

32. Gerber C, Schneeberger AG, Hoppeler H, Meyer DC. Correlation of atrophy and fatty infiltration on strength and integrity of rotator cuff repairs: a study in thirteen patients. J Shoulder Elbow Surg. 2007;16:691-6.

33. Gladstone JN, Bishop JY, Lo IK, Flatow EL. Fatty infiltration and atrophy of the rotator cuff do not improve after rotator cuff repair and correlate with poor functional outcome. Am J Sports Med. 2007;35:719-28.

34. Liem D, Lichtenberg S, Magosch P, Habermeyer P. Magnetic resonance imaging of arthroscopic supraspinatus tendon repair. J Bone Joint Surg Am. 2007;89:1770-6.

35. Melis B, DeFranco MJ, Chuinard C, Walch G. Natural history of fatty infiltration and atrophy of the supraspinatus muscle in rotator cuff tears. Clin Orthop Relat Res. 2010;468:1498505.

36. Hersche O, Gerber C. Passive tension in the supraspinatus musculotendinous unit after long-standing rupture of its tendon: a preliminary report. J Shoulder Elbow Surg. 1998;7:393-6.

37. Gimbel JA, Mehta S, Van Kleunen JP, Williams GR, Soslowsky LJ. The tension required at repair to reappose the supraspinatus tendon to bone rapidly increases after injury. Clin Orthop Relat Res. 2004;426:258-65.

38. Gimbel JA, Van Kleunen JP, Mehta S, Perry SM, Williams GR, Soslowsky LJ. Supraspinatus tendon organizational and mechanical properties in a chronic rotator cuff tear animal model. J Biomech. 2004;37:739-49.

39. Coleman SH, Fealy S, Ehteshami JR, et al. Chronic rotator cuff injury and repair model in sheep. J Bone Joint Surg Am. 2003;85:2391-402.

40. Bassett RW, Cofield RH. Acute tears of the rotator cuff. The timing of surgical repair. Clin Orthop Relat Res. 1983;175:1824.

41. Park JS, Park HJ, Kim SH, Oh JH. Prognostic factors affecting rotator cuff healing after arthroscopic repair in small to medium-sized tears. Am J Sports Med. 2015;43:2386-92.

42. Bedi A, Dines J, Warren RF, Dines DM. Massive tears of the rotator cuff. J Bone Joint Surg Am. 2010;92:1894-908.

43. Clement ND, Hallett A, MacDonald D, Howie C, McBirnie J. Does diabetes affect outcome after arthroscopic repair of the rotator cuff? J Bone Joint Surg Br. 2010;92:1112-7.

44. Sherman SL, Lyman S, Koulouvaris P, Willis A, Marx RG. Risk factors for readmission and revision surgery following rotator cuff repair. Clin Orthop Relat Res. 2008;466:608-13.

45. Galatz LM, Silva MJ, Rothermich SY, Zaegel MA, Havlioglu N, Thomopoulos S. Nicotine delays tendon-to-bone healing in a rat shoulder model. J Bone Joint Surg Am. 2006;88:2027-34.

46. Mallon WJ, Misamore G, Snead DS, Denton P. The impact of preoperative smoking habits on the results of rotator cuff repair. J Shoulder Elbow Surg. 2004;13:129-32.

47. Cummins CA, Murrell GA. Mode of failure for rotator cuff repair with suture anchors identified at revision surgery. J Shoulder Elbow Surg. 2003;12:128-33.

48. Piasecki DP, Verma NN, Nho SJ, et al. Outcomes after arthroscopic revision rotator cuff repair. Am J Sports Med. 2010;38:40-6.

49. Lo IK, Burkhart SS. Arthroscopic revision of failed rotator cuff repairs: technique and results. Arthroscopy. 2004;20:25067.

50. Djurasovic M, Marra G, Arroyo JS, Pollock RG, Flatow EL, Bigliani LU. Revision rotator cuff repair: factors influencing results. J Bone Joint Surg Am. 2001;83:1849-55.

51. Neviaser RJ. Evaluation and management of failed rotator cuff repairs. Orthop Clin North Am. 1997;28:215-24.

52. Sonnabend DH, Howlett CR, Young AA. Histological evaluation of repair of the rotator cuff in a primate model. J Bone Joint Surg Br. 2010;92:586-94.

53. Athwal GS, Sperling JW, Rispoli DM, Cofield RH. Deep infection after rotator cuff repair. J Shoulder Elbow Surg. 2007;16:306-11.

54. Herrera MF, Bauer G, Reynolds F, Wilk RM, Bigliani LU, Levine WN. Infection after mini-open rotator cuff repair. J 
Kyungil Kim and Jinyoung Jeong

Shoulder Elbow Surg. 2002;11:605-8.

55. Castoldi F, Blonna D, Hertel R. External rotation lag sign revisited: accuracy for diagnosis of full thickness supraspinatus tear. J Shoulder Elbow Surg. 2009;18:529-34.

56. Walch G, Boulahia A, Calderone S, Robinson AH. The 'dropping' and 'hornblower's' signs in evaluation of rotator-cuff tears. J Bone Joint Surg Br. 1998;80:624-8.

57. Burkhart SS, Tehrany AM. Arthroscopic subscapularis tendon repair: technique and preliminary results. Arthroscopy. 2002;18:454-63.

58. Motamedi AR, Urrea LH, Hancock RE, Hawkins RJ, Ho C. Accuracy of magnetic resonance imaging in determining the presence and size of recurrent rotator cuff tears. J Shoulder Elbow Surg. 2002;11:6-10.

59. Hayashida K, Tanaka M, Koizumi K, Kakiuchi M. Characteristic retear patterns assessed by magnetic resonance imaging after arthroscopic double-row rotator cuff repair. Arthroscopy. 2012;28:458-64.

60. Burkhart SS, Barth JR, Richards DP, Zlatkin MB, Larsen M. Arthroscopic repair of massive rotator cuff tears with stage 3 and 4 fatty degeneration. Arthroscopy. 2007;23:347-54.

61. Prickett WD, Teefey SA, Galatz LM, Calfee RP, Middleton WD, Yamaguchi K. Accuracy of ultrasound imaging of the rotator cuff in shoulders that are painful postoperatively. J Bone Joint Surg Am 2003;85:1084-9.

62. Jost B, Zumstein M, Pfirrmann CW, Gerber C. Long-term outcome after structural failure of rotator cuff repairs. J Bone Joint Surg Am. 2006;88:472-9.

63. Namdari S, Donegan RP, Chamberlain AM, Galatz LM, Ya- maguchi K, Keener JD. Factors affecting outcome after structural failure of repaired rotator cuff tears. J Bone Joint Surg Am. 2014;96:99-105.

64. Lädermann A, Denard PJ, Burkhart SS. Midterm outcome of arthroscopic revision repair of massive and nonmassive rotator cuff tears. Arthroscopy. 2011;27:1620-7.

65. Levy O, Mullett H, Roberts S, Copeland S. The role of anterior deltoid reeducation in patients with massive irreparable degenerative rotator cuff tears. J Shoulder Elbow Surg. 2008;17:863-70.

66. Wong I, Burns J, Snyder S. Arthroscopic GraftJacket repair of rotator cuff tears. J Shoulder Elbow Surg. 2010;19:S104-9.

67. Bailey JR, Kim C, Alentorn-Geli E, et al. Rotator cuff matrix augmentation and interposition: a systematic review and meta-analysis. Am J Sports Med. Published online June 1, 2018; doi: 10.1177/0363546518774762.

68. Mallon WJ, Wilson RJ, Basamania CJ. The association of suprascapular neuropathy with massive rotator cuff tears: a preliminary report. J Shoulder Elbow Surg. 2006;15:395-8.

69. Lafosse L, Tomasi A, Corbett S, Baier G, Willems K, Gobezie R. Arthroscopic release of suprascapular nerve entrapment at the suprascapular notch: technique and preliminary results. Arthroscopy. 2007;23:34-42.

70. Craig EV. Techniques for full thickness rotator cuff repairs. In: Craig EV, ed. Master techniques in orthopaedic surgery: the shoulder. Philadelphia: Lippincott; 2004. 309-40.

71. Bell RH, Noel CR. Arthroscopic repair of the rotator cuff. In: Craig EV, ed. Master techniques in orthopaedic surgery: the shoulder. Philadelphia: Lippincott; 2004. 35-57. 


\section{견관절 수술 후 재수술}

\section{회전근 개 재파열 후 봉합술 \\ 김경일•정진영 \\ 가톨릭대학교 성빈센트병원 정형외과}

대부분의 환자는 관절경적 회전근 개 봉합술 후 통증이 완화되고 기능적 호전을 보이지만 일부 환자는 수술 후에도 증상이 지속된 다. 재파열은 생물학적, 기술적, 외상적 요인이 복합적으로 작용하여 발생한다. 회전근 개 봉합술 후 재파열이 지속되는 통증의 원인 일 수도 원인이 아닐 수도 있다. 따라서 이런 환자들의 평가 및 치료는 난해하여 철저한 문진, 이학적 검사, 적절한 영상 검사를 통해 서 통증의 원인에 대한 분석이 이루어져야 한다. 재봉합술의 시행 여부는 환자의 나이, 기능적 요구도 회전근 개의 상태, 수술 전 관 절 운동 범위, 삼각근의 상태, 관절과 상완 관절의 관절염의 유무에 따라 결정되어야 한다. 성공적인 재봉합술은 술기뿐만 아니라 수 술 전 환자 교육 또한 중요하다.

색인단어: 회전근 개 봉합술, 관절경적 회전근 개 봉합술, 회전근 개 봉합술 후 재파열, 회전근 개 재파열 후 봉합술, 관절경 적 회전근 개 재봉합술

접수일 2018년 8월 7일 수정일 2018년 10월 23일 게재확정일 2019년 1월 28일

책임저자 정진영

16247 , 수원시 팔달구 중부대로 93 , 가톨릭대학교 성빈센트병원 정형외과

TEL 031-249-7186, FAX 031-254-7186, E-mail osjeong@hotmail.com, ORCID https://orcid.org/0000-0003-0047-5391 